\title{
Riverine Microplastic Loading to Mersin Bay, Turkey on the North-Eastern Mediterranean
}

\author{
Ülkü Özgüler ${ }^{1}\left(\mathbb{D}\right.$, Aydeniz Demir ${ }^{1, *}\left(\mathbb{D}\right.$, Gülşah Can Kayadelen ${ }^{1,2}(\mathbb{D}$, Ahmet Erkan \\ Kıdeyş $^{2}$ (i)
}

\author{
${ }^{1}$ Mersin University, Faculty of Engineering, Department of Environmental Engineering, Yenişehir, 33347, Mersin, \\ Türkiye. \\ ${ }^{2}$ Middle East Technical University, Institute of Marine Science, Erdemli, 33731, Mersin, Türkiye.
}

\section{How to cite}

Özgüler, Ü., Demir, A., Can Kayadelen, G., Kıdeyş, A.E. (2022). Riverine Microplastic Loading to Mersin Bay, Turkey on the North-eastern Mediterranean, 22(SI), TRJFAS20253. http://doi.org/10.4194/TRJFAS20253

\section{Article History \\ Received 14 July 2021 \\ Accepted 20 January 2022 \\ First Online 2 February 2022 \\ Corresponding Author \\ Tel.: +903243610001/17093 \\ E-mail: aydenizdemir@mersin.edu.tr}

\section{Keywords}

Microplastic load

Mersin Bay

Mediterranean

River

\section{Introduction}

Plastics are a wide range of synthetic or semisynthetic polymers derived from fossil fuel-based petrochemicals. Plastics are an integral part of our daily life due to the fact that they are corrosion resistant, inert and affordable (Avio et al., 2017; Sun et al., 2018). Consequently, plastic demand and production are ever increasing; 368 million tons globally, 58 million tons for the EU countries (Plastics Europe, 2019), and 9.5 million tons for Turkey in 2019 (Pagev, 2020). The part of production which is recycled totals only $15 \%$ of manufactured plastics (Plastics Europe, 2019). Immense plastic production, improper disposal and insufficient recycling applications have led to outstanding plastic pollution in the environment. The primary source of plastic pollution is the manufacturing industry (Jambeck et al., 2015; Ding et al., 2019).
Plastic litter can be broken down into countless numbers of microplastic (MP) particles by anthropogenic activities and various physical and chemical processes on land, in the atmosphere and in aquatic environments. Particles smaller than $5 \mathrm{~mm}$ in size that tend to migrate, transform and accumulate in the environment are defined as microplastic (Pellini et al., 2018; Ding et al., 2019).

There are two main categories of microplastics (MPs); primary microplastics that are directly within the micrometer size range, such as fibres derived from fabric washing (Napper and Thompson, 2016) or microbeads from cosmetic products (Güven et al., 2017) and secondary microplastics caused by the fragmentation of larger pieces of plastic waste (Alam et al., 2019). Numerous studies have shown that microplastics are found almost everywhere on earth (Liu et al., 2018; Corradini et al., 2021) including throughout the entire 
water column (Zhang et al., 2017; Zheng et al., 2019) and sediments of marine and freshwater ecosystems (Tubau et al., 2015; Alam et al., 2019; Xia et al., 2020).

The increase in microplastics in the oceans has caused global concern, as it poses a threat to marine ecosystems and food security (Cheung et al., 2018; Yabanlı et al., 2019; Pan et al., 2019, Avio et al., 2017).

The oceans and seas are the major sink areas of plastic waste. Rivers carry up to $80 \%$ of the total macroplastic load to the ocean (Meijer et al., 2021). The annual amount of macroplastic waste from rivers to the oceans has recently been estimated at 0.8-2.7 million metric tons (Meijer et al., 2021). Every year 70 thousand to 130 thousand tons of plastics flow via rivers/streams into the seas in Europe, in particular to the Mediterranean (WWF, 2018). González-Fernández et al. (2021) estimated that between 307 and 925 million macrolitter items (of which $82 \%$ plastics) are released annually from Europe to the ocean. Their study comprising 42 rivers from Europe also included two Turkish rivers; Lamas River in Mersin and Göksu River in Istanbul carried 17,423 and 314,908 macrolitter items/year, to the Mediterranean and the Marmara Sea, respectively. Gonzalez-Fernendez et al. (2020) earlier showed a significant level of riverine transport of macroplastics to the Black Sea from 10 rivers around the Black Sea located in Ukraine, Russia, Georgia and Turkey. Riverine litter fluxes were variable, showing median values generally between 4 and 75 items/hour in the different rivers, however, it reached maximum values up to 700 items/hour for the River Firtına of Turkey in the southeastern Black Sea (GonzalezFernandez et al., 2021). These are the only data on the riverine transport of macroplastics for Turkey. All these data indicate that riverine systems play a major role in transporting macroplastics from land to the marine environment (Skalska et al., 2020).

The main route of external microplastics to the sea is also reported as riverine (Cheung et al., 2019) and secondarily wastewater discharges (Dikareva and Simon, 2019; Ryan et al., 2009). Microplastics cannot be removed effectively by wastewater treatment plants, and as a result, they transport significant amount of microplastics to the recipients' coastal waters (Estahbanati and Fahrenfeld, 2016, Akarsu et al., 2020). Anthropogenic factors along the river basins affect the amount and composition of microplastics transported in rivers (Wang et al., 2017). Worldwide, only $13 \%$ of the studies on microplastic pollution among all aquatic systems have been carried out in freshwater environments (Dahms et al., 2020). Recent researches on the freshwater systems have mainly focused on lakes and freshwater sediments, whilst relatively little information is available on MPs pollution in urban rivers (Lebreton et al., 2017) or their load to the seas (Alimi et al., 2018).

Microplastic concentrations in the rivers/streams studied were observed to vary substantially. It has been reported that the microplastic concentration in the surface of the Wei River varied from 3670 to 10700 items $/ \mathrm{m}^{3}$ (Ding et al., 2019). In a study conducted in the Limpopo River in Africa, the average microplastic concentration was found to be 705 particles $/ \mathrm{m}^{3}$ (Dahms et al., 2020). In another study, the amount of microplastics in the Zhangjiang River in China ranged from 50 to 725 items $/ \mathrm{m}^{3}$, with an average of 246 items $/ \mathrm{m}^{3}$ (Pan et al., 2020).

Mediterranean coastal waters are fed by freshwater sources from Europe, Asia, and Africa basins and are subjected to high population densities due to touristic popularity. Due to its semi-closed structure, the Mediterranean Sea is highly exposed to marine litter pollution (Cozar et al., 2015; Tubau et al., 2015). Mersin province, located in southern Turkey, has a $321 \mathrm{~km}$ long coastal strip along the northeastern Mediterranean. The population of Mersin city increases significantly during the summer season due to beach tourism. High levels of population and tourism contributed by intense port, maritime and fisheries activities and extensive agricultural production (dominantly in greenhouses covered with plastics) are responsible for plastics pollution in Mersin province. Thus, Mersin Bay is exposed to a significant microplastic pollution load (Gündoğdu et al., 2018, Güven et al., 2017) from the land mainly transported via rivers and waste water treatment plants (Akarsu et al., 2020).

For the Mersin province, there are only a couple of studies determining the amount of microplastics load to the Mediterranean from wastewater treatment plants (WWTPs) (Akarsu et al., 2020) and floods (Gündoğdu et al., 2018). Levels of microplastics in Mersin Bay sediments and surface waters were also determined earlier (Güven et al., 2017). Rivers are systems that provide a link between the terrestrial ecosystem and the aquatic ecosystem (such as seas and oceans), and like many other pollutants, they also transport microplastics into this aquatic environment. However, the levels of microplastics transported by the Mersin rivers have not yet undergone a through investigation. Up to our knowledge, except the recently published paper by Güven (2021) for the three Antalya rivers, no other study on determination of riverine load of microplastics for the seas (i.e. the Mediterranean, Marmara, and the Black Sea) surrounding Turkey has been undertaken until now. Therefore, the aim of the current study is to evaluate the quantities, composition, and loads of microplastics from the eight rivers/streams that flow to Mersin Bay, Turkey's north-eastern Mediterranean.

\section{Materials and Methods}

\section{Study Area}

Mersin province of Turkey covers $321 \mathrm{~km}$ of coastline along the north-eastern Mediterranean. Mersin Bay denotes the sea area from Taşucu in the west to Karataş in the east. Mersin Bay is under a significant pollution load due to its large port, free zone, 
the potential of local tourists, intense agriculture and due to Mersin city itself having a population of 1.8 million. Plastic consumption per capita in Mersin is 75 $\mathrm{kg}$, which is above the world average. In this study, 8 rivers (i.e. Alata, Arpaçbahşiş, Deliçay, Göksu, Kandak, Lamas, Mezitli and Müftü) were sampled for microplastics content and quantity (Figure 1). Information about the sampling point (only one) for each river is shown in Table 1 . Sampling points were generally less than $150 \mathrm{~m}$ from the sea, excluding Deliçay (728) and Göksu (5715 m). At these two rivers, due to the unfavorable terrain conditions we could not come close the places where the rivers flow into the sea. It is worth noting that the effluent of the Silifke waste water treatment plant (WWTP) discharges to the Göksu River approx. $12 \mathrm{~km}$ before the Göksu reaches the sea. Hence, our samples from this river also include microplastics contained in Silifke WWTP effluent, which was studied recently (Akarsu et al., 2020).

\section{Sample Collection and Processing}

Sampling was carried out during November 2019 after the long tourism season ended (Table 1). Using a measured beaker of 2 litres, a total of 150 - 200 litres of water sample was taken from the surface of each river at a point as close as possible to the sea (range 6-5715 $\mathrm{m}$; see Table 1). Water samples were filtered on site through a customized filtering apparatus of $10 \mathrm{~cm}$ in diameter pipe having a replaceable $26 \mu \mathrm{m}$ plankton mesh at its bottom (Figure 2). After the filtering process, each filter (i.e. $26 \mu \mathrm{m}$ plankton mesh) was transferred individually into a glass petri dish whilst in the field. 1-2 $\mathrm{mL}$ of hydrogen peroxide $\left(\mathrm{H}_{2} \mathrm{O}_{2}\right)$ was added to glass petri dishes to dissolve organic matter.

In general, the standard EC guidelines for the processing of microplastic samples were followed (European Commission, 2013). Each microplastic item on the mesh $(26 \mu \mathrm{m})$ was manually transferred onto

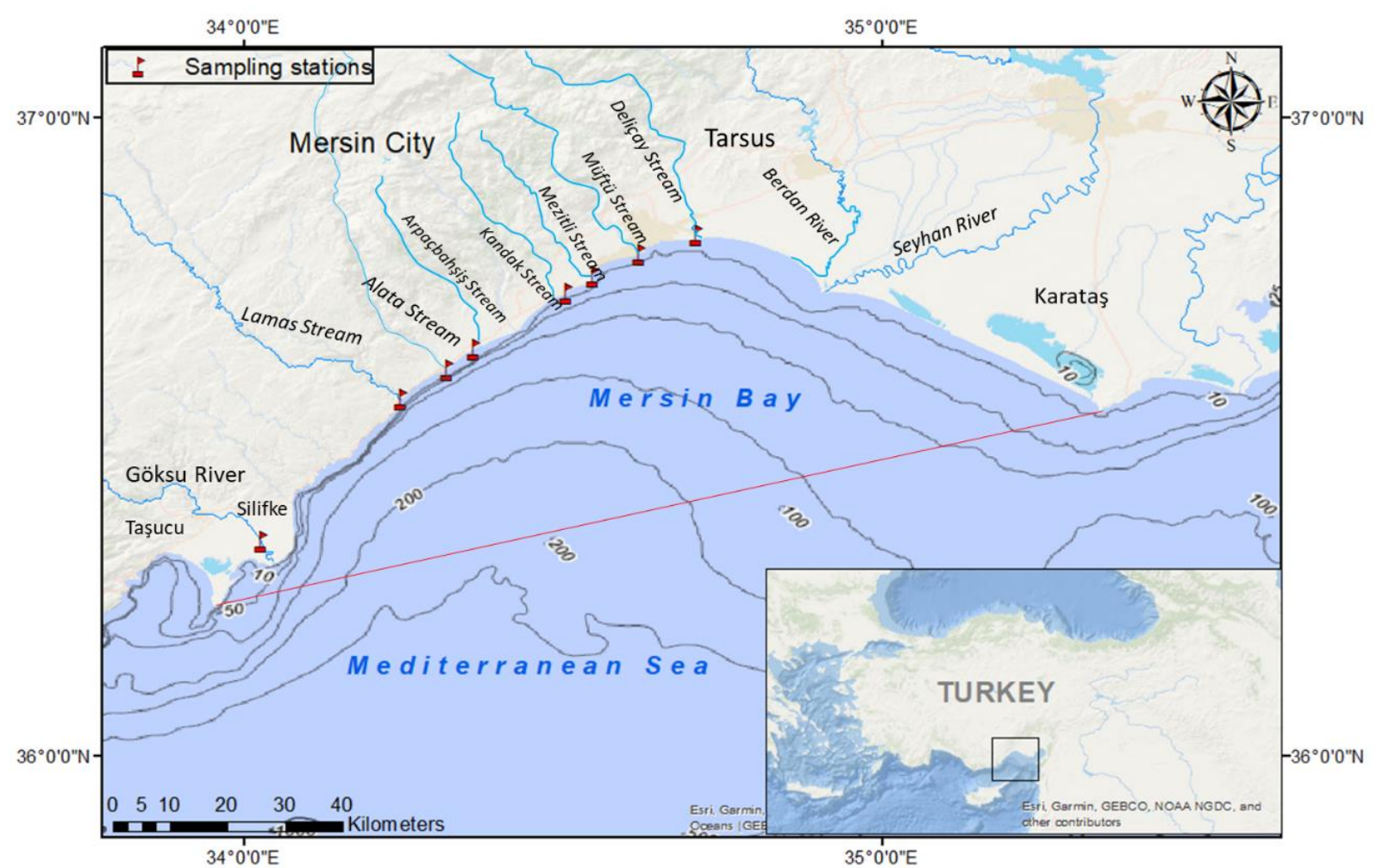

Figure 1. The eight rivers sampled in Mersin province. Turkey located on the north-eastern Mediterranean (Berdan and Seyhan rivers were not sampled but are shown due to their significant inflow to the Mersin Bay). The dotted line shows the assumed outer border of the Mersin Bay.

Table 1. Sampling information

\begin{tabular}{|c|c|c|c|c|}
\hline River & Date & \multicolumn{2}{|c|}{ Coordinate } & Distance from sea $(\mathrm{m})$ \\
\hline Arpaçbahşiş & 12.11 .2019 & $36^{\circ} 38^{\prime} 16^{\prime \prime} \mathrm{N}$ & $34^{\circ} 21^{\prime} 32^{\prime \prime} \mathrm{E}$ & 52 \\
\hline Lamas & 01.11 .2019 & $36^{\circ} 33^{\prime} 27^{\prime \prime} \mathrm{N}$ & $34^{\circ} 14^{\prime} 42^{\prime \prime} \mathrm{E}$ & 18 \\
\hline Alata & 01.11 .2019 & $36^{\circ} 36^{\prime} 14^{\prime \prime} \mathrm{N}$ & $34^{\circ} 19^{\prime} 10^{\prime \prime} \mathrm{E}$ & 6 \\
\hline Göksu & 01.11 .2019 & $36^{\circ} 20^{\prime} 15^{\prime \prime} \mathrm{N}$ & $34^{\circ} 01^{\prime} 16^{\prime \prime} \mathrm{E}$ & $5715^{*}$ \\
\hline Kandak & 12.11.2019 & $36^{\circ} 43^{\prime} 28^{\prime \prime} \mathrm{N}$ & $34^{\circ} 30^{\prime} 17^{\prime \prime} \mathrm{E}$ & 23 \\
\hline Mezitli & 01.11 .2019 & $36^{\circ} 45^{\prime} 04^{\prime \prime} \mathrm{N}$ & $34^{\circ} 32^{\prime} 45^{\prime \prime} \mathrm{E}$ & 140 \\
\hline Müftü & 12.11 .2019 & $36^{\circ} 47^{\prime} 05^{\prime \prime} \mathrm{N}$ & $34^{\circ} 37^{\prime} 10^{\prime \prime} \mathrm{E}$ & 88 \\
\hline Deliçay & 12.11.2019 & $36^{\circ} 48^{\prime} 52^{\prime \prime} \mathrm{N}$ & $34^{\circ} 42^{\prime} 21^{\prime \prime} \mathrm{E}$ & $728 *$ \\
\hline
\end{tabular}

* relatively long distances from the sea 
another filter paper (sterilized/pre-scanned for the presence of microplastics) under a stereomicroscope (up to 30x magnification) (Olympus SZX16). Non-plastic natural particles (i.e. wood, paper and other organic matter) were removed as they were relatively easily distinguished when touched with needle, when necessary after slightly heating the needle. The diameter/length of each individual microplastic particle was then measured using Olympus cellSens Image Analysis software. Microplastics separated under the stereo microscope were photographed with a DP26Olympus 5.0 MP high colour fidelity microscope digital camera. Only pieces of plastic litter with a length of $<5$ $\mathrm{mm}$ were considered as microplastic while pieces $>5$ $\mathrm{mm}$ were excluded from any further analysis.

During sample processing, utmost care was taken to prevent fibre contamination (e.g. cotton laboratory coats worn at all times). Since we did not do filtration procedure in the laboratory (but in the field), contamination possibility was minimal. Glass petri dishes were opened only for adding $\mathrm{H}_{2} \mathrm{O}_{2}$, for transferring particles onto another filter under the microscope and for microscopy analysis. A control glass petri dish was kept beside the microscope for the same period to evaluate for any potential contamination during these processes, however, generally no contamination occurred during such short period. Any other potential contamination during these processes cannot explicitly be ruled out due to the intrinsic nature of the study, however if any additional contamination did occur it is likely to be negligible.

\section{Identification of MPs with ATR-FTIR}

Fourier Transform Infrared (FTIR) Spectroscopy analysis (using a Bruker tensor 27 equipment) was performed on the sampled microplastics for polymer characterization. Among the larger ones (>2 mm), 31 non-fibre particles were randomly selected belonging to Arpaçbahşiş (21 particles) and Deliçay Rivers (10 particles) for FTIR spectroscopy analysis to verify that the collected particles were indeed plastic polymers. Polymer types for microplastic subsamples were identified by comparison of spectra with ranges obtained from the ATR-FTIR (Alpha Platinum) spectrometer library in the Central Laboratory of the Turkish Ministry of Agriculture and Forestry.

\section{Results and Discussion}

\section{Distribution of Form, Colour and Size of MPs}

In this study, a total of 449 microplastic particles $<5$ $\mathrm{mm}$ were observed in the water samples (and other five particles larger than $5 \mathrm{~mm}$ ). Microplastic forms are presented in Figure 3 for each river as well as for all rivers combined. The dominant form of microplastics observed in these study samples was fibres with an overall share of $84 \%$. The lowest levels of microplastics were obtained from Deliçay (50\%) and Arpaçbahşiş (61\%). The contributions of fragment and film forms of microplastics to the total abundance in the obtained samples were only 9 and $7 \%$, respectively.

Particles spotted under the microscope were labelled as one of four major categories of microplastics: fragments, films, fibres and others (styrofoam or polystyrene, rubber, paint flake etc.). Fragments may result from for example, fragmented PET bottle caps or similar hard macroplastic products, whilst films may originate from disintegrated shopping bags or green house coverings. Microplastic particles for each form were also categorised based on their colour.

The dominance of fibres in riverine microplastics was also noted in other studies from the literature

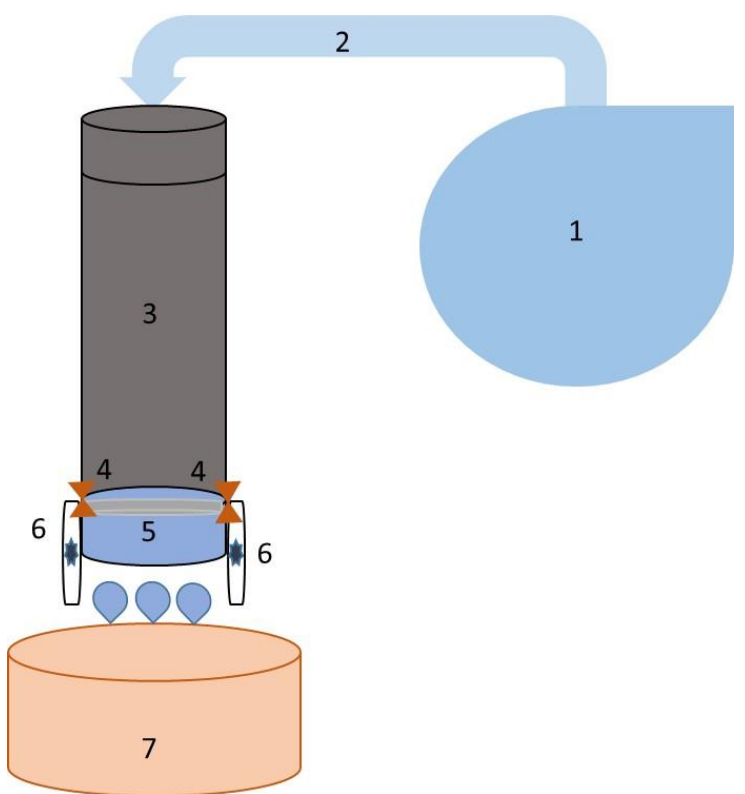

Figure 2. Sampling and filtration of microplastics from Mersin Rivers (1: River/stream, 2: Sampled water, 3: Filtering apparatus/pipe 4: Valve, 5: Plankton mesh of $26 \mu \mathrm{m}, 6$ : Valve holder 7: Water filtered. 
(Mason et al., 2016; Pan et al.; 2020). For example, Zhao et al. (2020), found mostly fibre (53\%) particles in water surface samples from the Qiantang River, China following filtration through $45 \mu \mathrm{m}$ mesh. These authors suggested that the prevalence of fibres was due to an intensive textile industry in the studied area. In another study conducted using a $100 \mu \mathrm{m}$ nylon mesh for filtration, fibre particles made up the bulk (95\%) of microplastics in the open waters and sediment of the Ottawa River, Canada, and its tributaries (Vermaire et al., 2017). Fibre microplastics are often released from the shedding or disintegration of synthetic fibre garments, blankets and other products (Belzagui et al., 2019; Liu et al., 2019). These products that are used by the population living in the catchment areas could be the source of fibre pollution (Sang et al., 2021) which could be transported to rivers via rainfall and the atmosphere. The importance of rainfall in fibre pollution for the sewage systems has been shown in previous studies (Akarsu et al. 2020; Park et al., 2020). Dominance of fibres (about 70\% overall) in the effluent waters of the three waste water treatment plants (WWTPs) flowing to Mersin Bay has also been reported recently (Akarsu et al., 2020). Similar to the composition in rivers (and WWTPs), fibres were the most common microplastics form found in waters, sediment, and fish (70\% of all ingested items) in the Mersin bay (Güven et al., 2017).

The colour distribution of sampled microplastics was also analyzed in the present study (Figure 4). Over half of the microplastics observed were blue in colour (55\%), followed by black (30\%), transparent (9\%) and red $(3 \%)$. These results are in concordance with those obtained from other similar studies. For example, both Yan et al. (2019) and Wang et al. (2020) observed that the colour distribution of microplastics is mostly in blue, black and transparent colours for the Chinese riverine ecosystems. Napper et al. (2021) found that blue (74\%) was the dominant microplastics colour in the Ganges River, followed by black (11\%), red (6\%), purple (4\%), and brown (2\%), respectively.

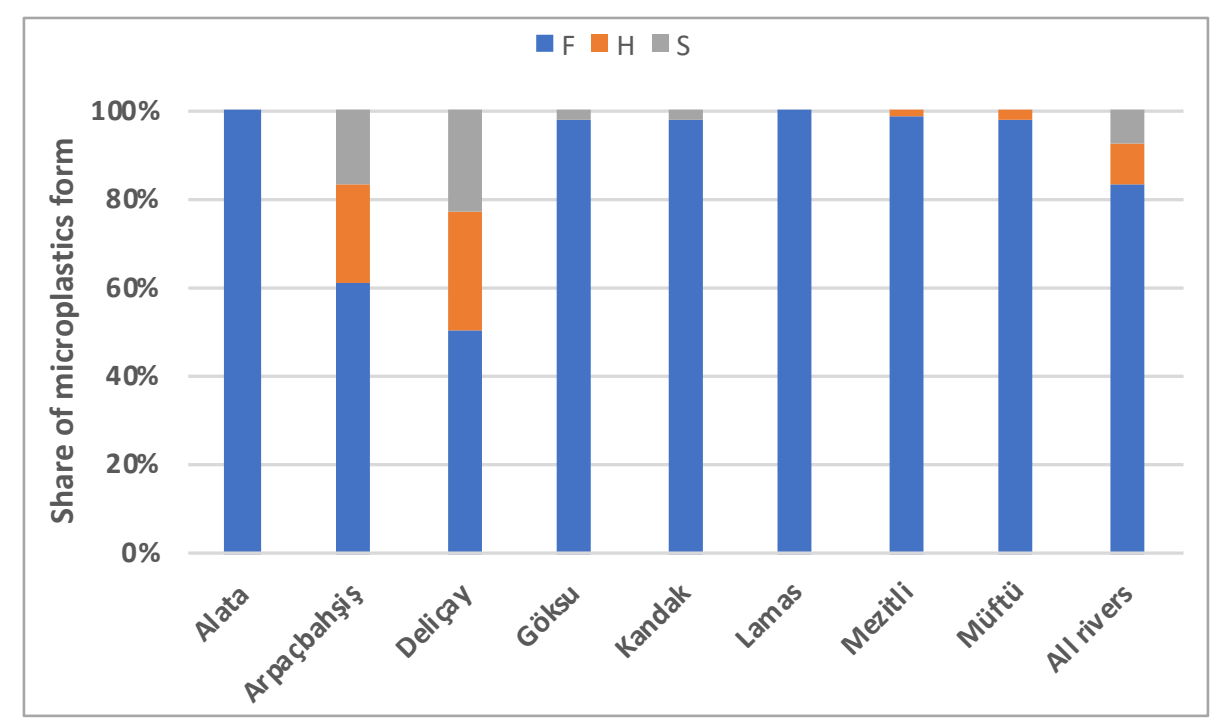

Figure 3. Percentage of microplastic forms found in Mersin Rivers ( ${ }^{*} \mathrm{~F}$ : Fibre $-\mathrm{H}$ : Fragment $-\mathrm{S}$ : Film).

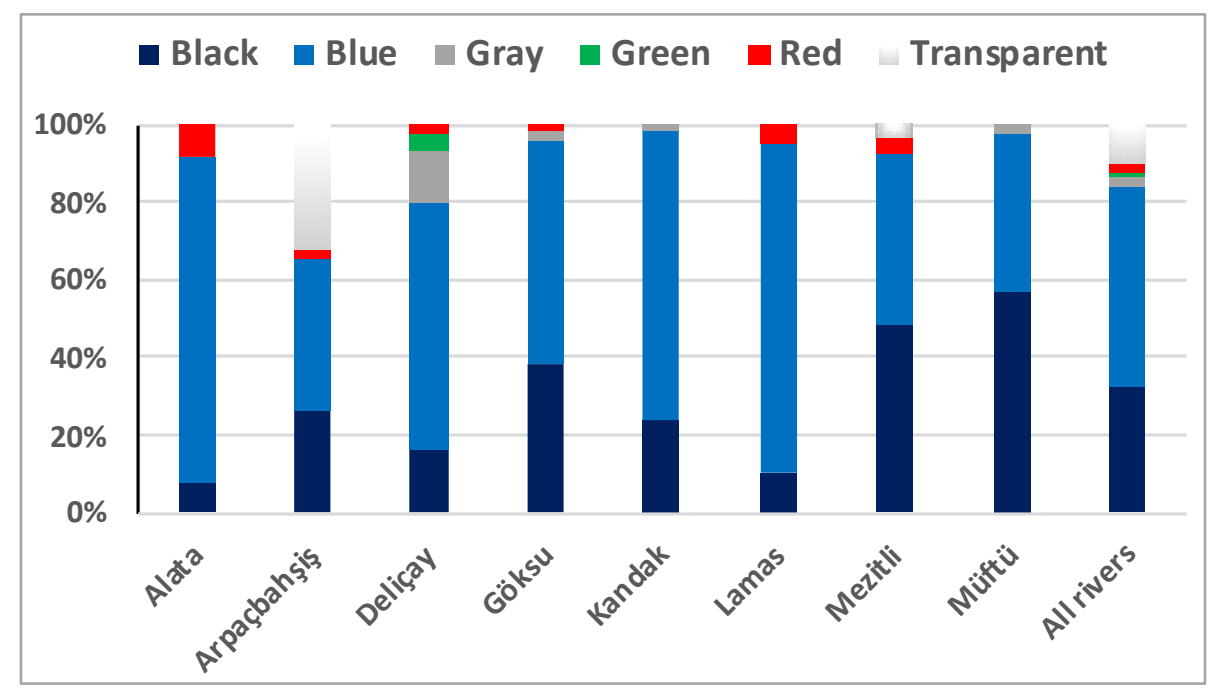

Figure 4. Colour distribution of sampled microplastics. 
Fortin et al. (2019) found that the most common colour of detected MPs was black. The main colours observed from the effluent waters of the three WWTPs in Mersin were also very similar to our results; blue (about 27\%), black (about 22\%), transparent (13\%) and red (13\%) (based on recalculation of data of Akarsu et al. 2020). Güven et al. (2017) reported that $78 \%$ of the microplastics were blue in colour (followed by black and red) found in the digestive systems of fish sampled in Mersin Bay. Dominance of the same colours both in the pathways (rivers for this study and WWTPs in Akarsu et al., 2020) and in fishes obtained from the recipient waters (i.e. Mersin Bay, Güven et al., 2017), indicates the significance of terrestrial transport of microplastics for the marine environment. Transparent colour was observed almost exclusively for fragment and film microplastics, with the highest percentage in Arpaçbahşiş samples (38\%). The main sources of film transparent microplastics are likely to be either single use plastic carrier bags or greenhouse coverings greenhouse coverings for agricultural production. It has been reported that properties of plastic waste such as size, form, shape and polymer type are the main driving force in its transportation (Schwarz et al., 2019). The vertical movement of plastics in water, or the rate of precipitation, is often affected by density and particle size (Kowalski et al., 2016; Schwarz et al., 2019). Small plastic particles are more easily transported by runoff, and large particles can often remain in the river tributaries (Hurley and Nizzetto, 2018). Figure 5 shows the size frequency distribution of microplastics determined at all sampling points. The average microplastic length $(\mu \mathrm{m})$ for each river and for all rivers combined is given in Figure 6.

In this study, over $91 \%$ of microplastics detected in riverine waters were less than $2.5 \mathrm{~mm}$ in length (Figure $5)$. Interestingly, the same value $(91 \%)$ was calculated for the share of the size range of $0.4-2.5 \mathrm{~mm}$ of all microplastics detected in the effluent waters of the three WWTPs of Mersin (recalculated from Akarsu et al., 2020). Similarly, Güven et al. (2017) reported that $94 \%$ of all MPs collected in the samples from the surface waters, water column, and sediment of the Mediterranean were between 0.1 and $2.5 \mathrm{~mm}$. Microplastics found in the samples taken from the Pearl River were also mostly between $0.5-2 \mathrm{~mm}$ (Cheung et al., 2018). Some rivers reported in the literature had the dominance of even smaller microplastics. For example, Yan et al. (2019) and Wang et al. (2020) found that $80 \%$ and $85 \%$ of microplastics were smaller than $0.5 \mathrm{~mm}$, respectively (in our study only $14 \%$ were $<0.5 \mathrm{~mm}$ ).

However, the average size of microplastics differed among the rivers investigated in our study (Figure 6). Whilst the Göksu River revealed the smallest microplastics with an average size of $0.79 \mathrm{~mm}$, Mezitli displayed the largest average size of $1.47 \mathrm{~mm}$, followed by Alata with a value of $1.44 \mathrm{~mm}$. The latter two rivers/streams pass through the intensely populated areas in the study region. In any case, as the length of microplastics decreases, their number increases (Figure 5 and 6). Napper et al. (2021) reported that the average size of microplastics was $2459 \pm 209 \mu \mathrm{m}$ in the Ganges River. They suggested lack of effluent from any WWTP into Ganges River as the reason for the relatively large size of microplastics in their study. Microplastics from wastewater treatment plants are usually smaller than $0.5 \mathrm{~mm}$ (Mason et al., 2016; Yan et al., 2019). The relatively larger sizes in their study indicated that they were secondary microplastics, that is, larger plastic items which have gradually degraded into smaller particles (Zhang et al.; 2015). The transport of smaller microplastics to the sea, especially those smaller than 2 $\mathrm{mm}$ in size, poses a greater risk to marine organisms (Lam et al., 2020). Additionally, because small size microplastics provide larger surface area/volume ratios, higher concentrations of heavy metals and organic pollutants in the ambient water could be adsorbed on them (Pan et al., 2021). Previous studies show that microplastic ingestion by aquatic organisms has become common due to the increasing similarity to plankton species as the particles become smaller in size (Su et al., 2019). Güven et al. (2017) reported that the average MP size extracted from the stomach and intestines of 28 fish species sampled was $0.6 \mathrm{~mm}$ in Mersin Bay. Only 5 out of 1822 particles were longer than $5 \mathrm{~mm}$ in length. Bellas et al. (2016) reported that $17.5 \%$ of 212 fish collected from the Western Mediterranean and Atlantic Ocean had ingested microplastics with the most dominant size class being $0.5-1.0 \mathrm{~mm}$. These findings show that the smaller the particle size, the higher the chance of being ingested by different marine organisms (Wright et al., 2013).

\section{Microplastic Identification Using ATR-FTIR}

Thirtyone non-fibre particles obtained from rivers were analyzed by ATR-FTIR and it was confirmed that all of these analyzed particles were of plastic origin. The FTIR spectra and images under the microscope of some polymers detected in Arpaçbahşiş and Deliçay is given in Figure 7 and 8 . The bulk of the samples (24 out of 31 particles) was identified as polyethylene (PE), three each as polyvinyl chloride (PVC), cellulose, and one polypropilen. PE is one of the most widely produced polymers in the world and have been widely detected in microplastics research (Xiong et al., 2019; Sang et al., 2021). For example, Eerkes-Medrano et al. (2015) and Zheng et al. (2019) both showed that PE is the main microplastic polymer type seen in freshwater systems and riverine estuaries. 186 (43\%) from a total of 431 particles sampled from seawater and sediment of Mersin Bay in 2017 and analyzed by FTIR were also polyethylene (unpublished data of A. E. Kideys). Polyethylene is one of the cheapest and most widely used polymer types and is a common component of daily life in products such as disposable bags, food packaging, toys and household items (Akarsu et al., 2020). Sang et al. (2021) reported that the polymer 


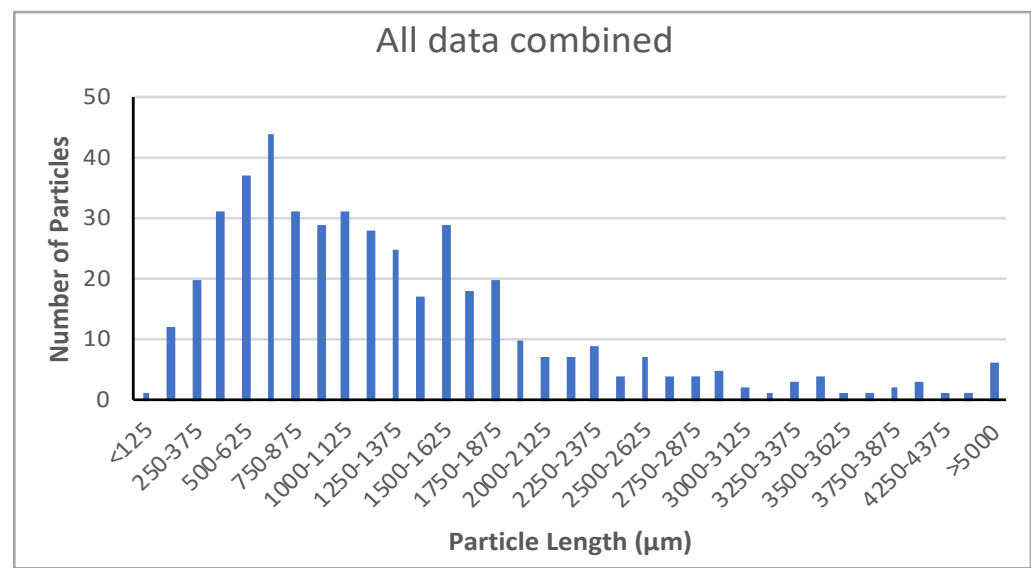

Figure 5. Size frequency distribution of microplastics (all data combined).

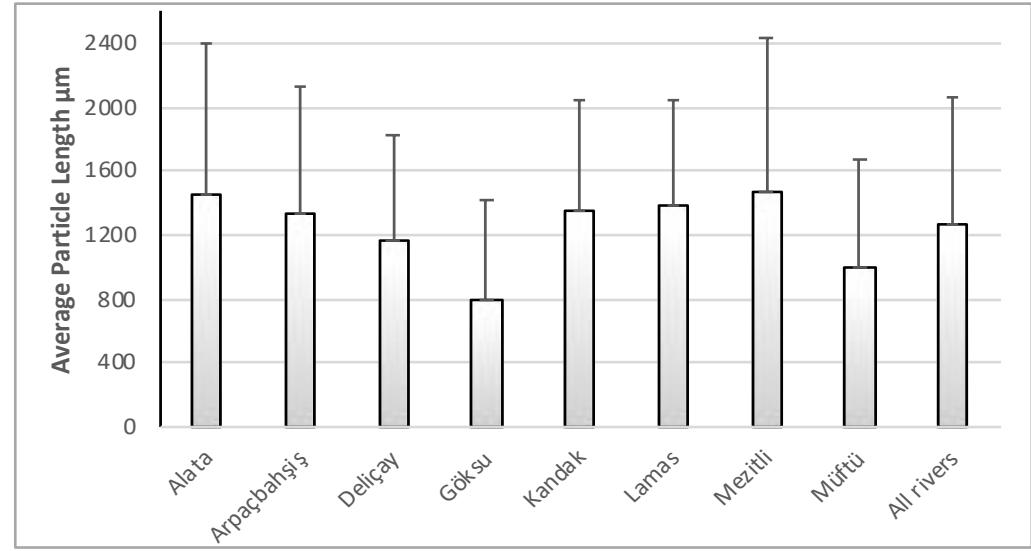

Figure 6. Average microplastic lengths $(\mu \mathrm{m})$ for each river and for all rivers combined.
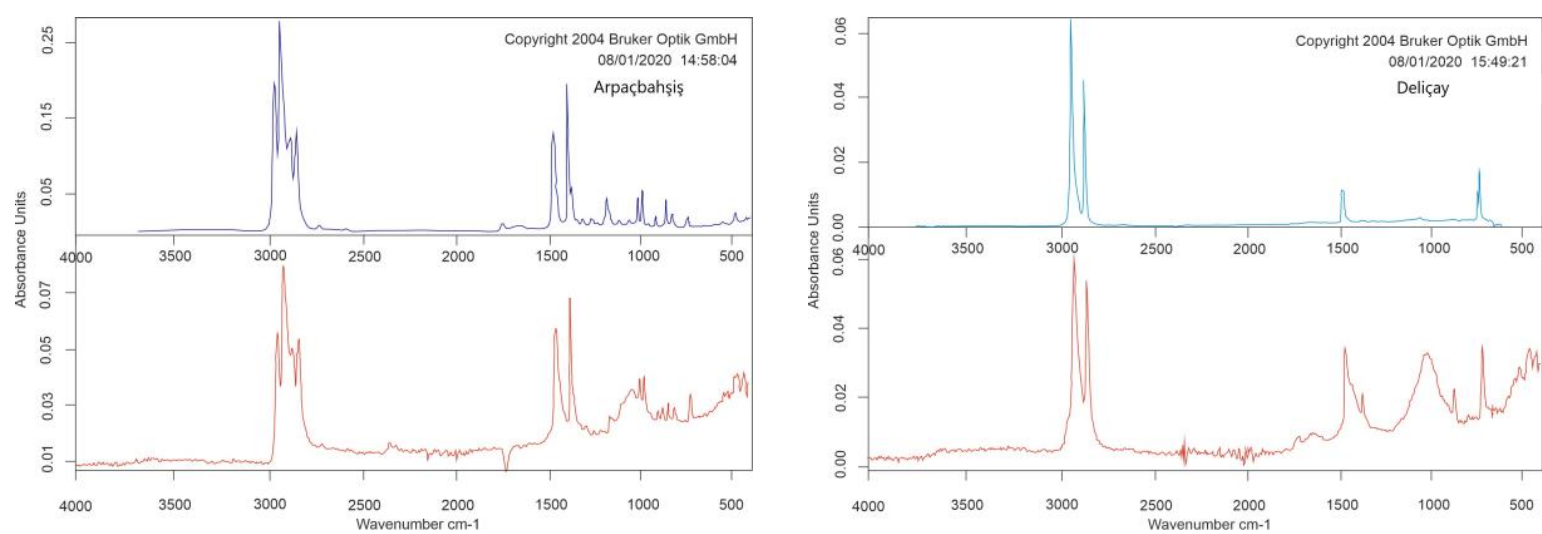

Figure 7. FTIR spectra of PP (Arpaçbahşiş) and PE (Deliçay) polymers detected in our study.
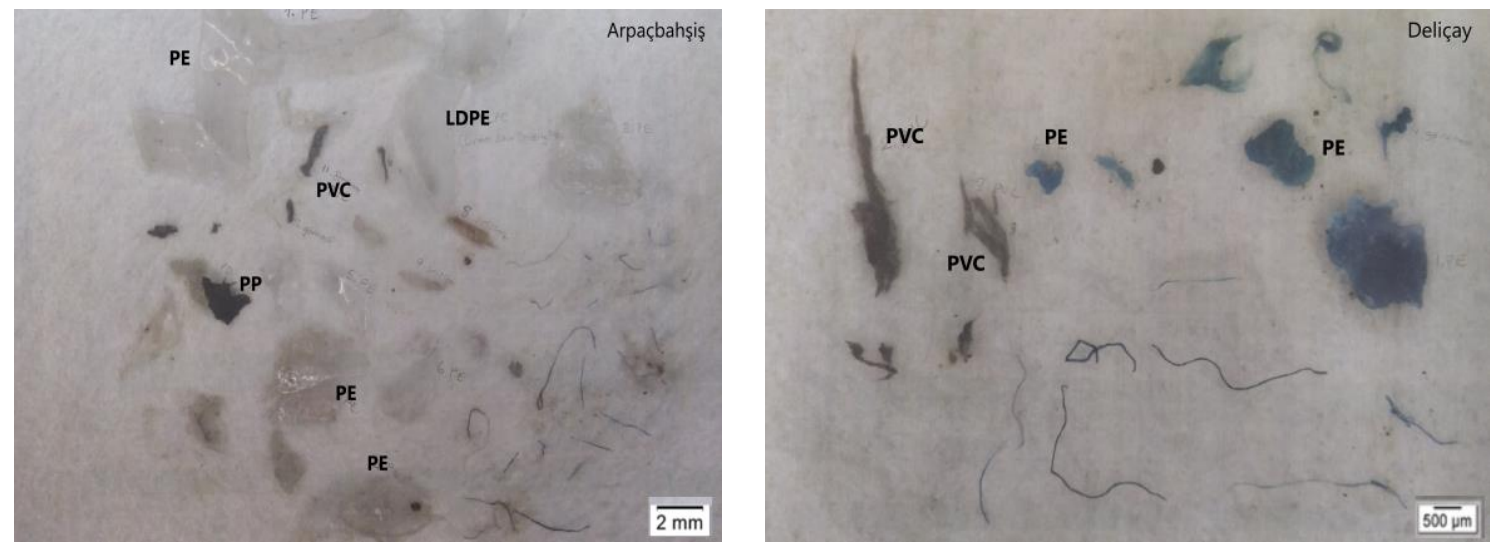

Figure 8. Microscopic images of some microplastics sampled from Arpaçbahşiş and Deliçay. 
types of microplastics in the water samples were mainly PE (41.7\%), followed by PP (31.3\%) and PET (20.7\%), with much lower proportions of PVC (4.2\%) and PS (2.1\%). He et al. (2020) reported that the three main polymers found in Brisbane River sampling sites are polyethylene (70\%), polyamide (12\%) and polypropylene (10\%). Literature reviews show that the probability of detected MPs being polyethylene varies between 4-51\% (Sun et al., 2019).

Due to the intensively greenhouse cultivation at our sampling sites, samples of the greenhouse coverings purchased locally were also analyzed by FTIR and the polymer form was mostly found to be polyethylene (PE). This indicates that besides plastic shopping bags (carrier bags), greenhouse coverings may also be a source of microplastics for rivers, WWTPs and eventually for the sea in the northeastern Mediterranean. In the FTIR analysis, it was determined that the detected polymers were not only in monomeric structure, and some of them consisted of additive-containing polymers.

\section{Microplastics Concentration and Load}

In this study, microplastic concentration and load from eight streams/rivers along the $117 \mathrm{~km}$ of coastline flowing into the Mersin Bay, the north-eastern Mediterranean were also determined.

As can be seen in Figure 9, the average microplastics concentrations among the sampled streams/rivers varied significantly (ANOVA, $p=0.002$ ) ranging between 95 (Lamas River) and 613 items $/ \mathrm{m}^{3}$ (Arpaçbahşiş River) with an overall average of $293 \pm 59$ items $/ \mathrm{m}^{3}$. Intense agricultural activities coupled with tourism from large numbers of high-rise holiday apartments in the latter region are considered to be the reason for this result. Previous studies of both freshwaters and beach shorelines have reported that high concentrations of microplastic pollution occur in densely populated areas (Horton and Dixon, 2018; He et al., 2020). Substantial numbers of microplastics (600 items $/ \mathrm{m}^{3}$, Akarsu et al., 2020) in the effluent of Silifke WWTP flowing to the Göksu River at $7 \mathrm{~km}$ upstream may be one of the reasons for the second highest values $\left(344 \pm 182\right.$ items $\left./ \mathrm{m}^{3}\right)$ in this river among all locations sampled in our study.

A comparison of microplastics levels between this study and other sampled rivers is given in Table 2. Our values were much higher than that average $(0.25 \pm 0.08$ items $/ \mathrm{m}^{-3}$ ) of three Antalya rivers of Turkey on the Mediterranean coast as well as than those observed in European rivers, but lower than the majority of southeast Asian rivers (Table 2). For example, average values as high as $1183 \pm 269$ items $/ \mathrm{m}^{3}$ and $5850 \pm 3280$ items $/ \mathrm{m}^{3}$ have been reported for some Chinese and Indonesian rivers, which are 4-20 fold higher than the average values found in our study. Conversely, a range of $0.9-1.3$ items $/ \mathrm{m}^{3}$ obtained for the Ofanto River flowing to the Adriatic is much lower than the range of 95-613 items $/ \mathrm{m}^{3}$ reported here. Differences in sampling techniques and equipment used (such as the plankton net mesh size) and analysis methods create challenges when comparing the results of our study with other studies in the literature (Vermaire et al., 2017).

It is worth noting that concentration values of microplastics in riverine environments are affected by many factors such as wind, river runoff, tributary inputs, and anthropogenic factors such as wastewater treatment plants and daily plastic consumption ( $\mathrm{Yu}$ et al., 2020). Once microplastics reach the sea, some, also due to fouling on particles, could sink and some others could spend some time in the Mersin Bay until they are transported out of the bay by the dominant westerly currents.

The marine environment is the largest recipient of terrestrial microplastics. Rivers/streams, together with WWTPs and atmospheric inputs, are among the most important pathways of transportation for macro and microplastics from land to the marine environment (Lin et al., 2018; Zhao et al., 2020). It is estimated that between 1.15 and 2.41 million tonnes of macroplastic waste in the terrestrial environment are transported to the seas and oceans via the global riverine system every year (Lebreton et al., 2017).

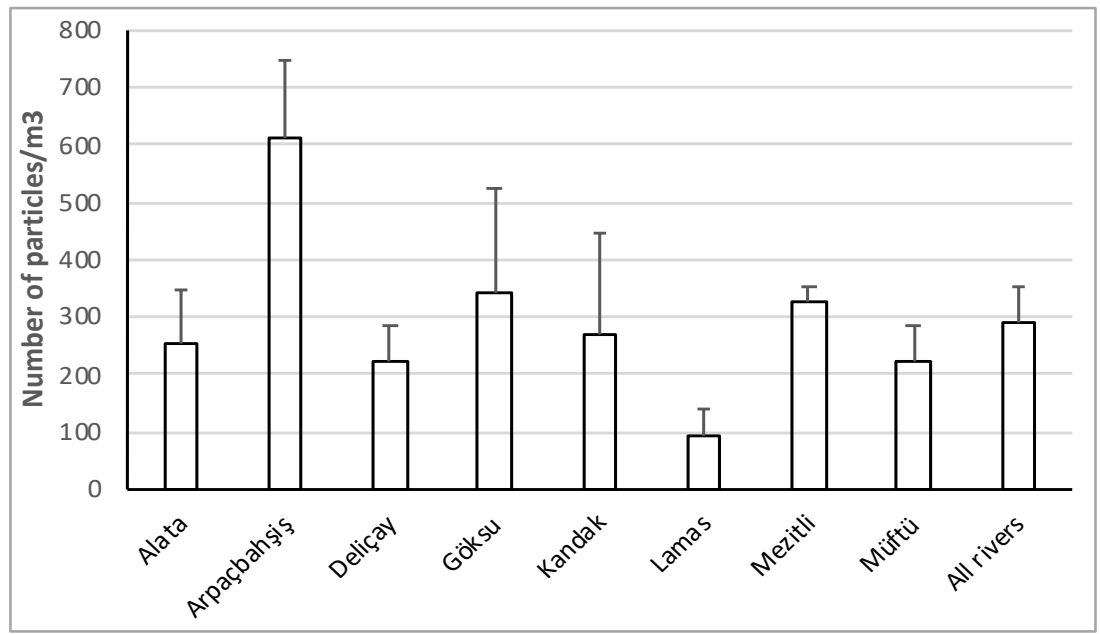

Figure 9. Average microplastic concentrations in Mersin Rivers (lines on bars are standard deviations). 
Table 3 shows the riverine microplastic load to the Mersin Bay in the northeastern Mediterranean. The microplastic load from each river was calculated using and the data obtained from this study and the flow rates of the rivers/streams from the literature (www.dsi.gov.tr/Sayfa/Detay/744). The eight rivers studied which flow to Mersin Bay constitute a total inflow rate of $99.41 \mathrm{~m}^{3} / \mathrm{s}$ of which almost $84 \%$ is due to the Göksu River (Table 3). Considering inflow rates and concentrations of microplastics in each river, the total pollutant load from the eight rivers studied to Mersin Bay was also calculated in this study. It is acknowledged that the flow dynamics of a river affect the concentration and load of microplastics; i.e. high river flow rates increase mobility and transport of plastic particles (Rodrigues et al., 2018). When the flow rate of the water decreases, plastic particles will probably start to settle (Horton and Dixon, 2018). Consequently, higher microplastic loads will be discharged to the sea from the faster flowing rivers.

Accordingly, we have estimated that the bulk load of microplastics among the rivers sampled in our study is transported by Göksu River with over $913 \times 10^{9}$ items per year due to its high flow rate, followed by Alata river with a value of only $25 \times 10^{9}$ items per year.

It is worth noting that the Göksu River also transports microplastics discharged from Silifke WWTP effluent $7 \mathrm{~km}$ upstream. The annual load of microplastics from Silifke WWTP has been calculated as $2.6 \times 10^{9}$ items per year (Akarsu et al. 2020), which amounts to only $3 \%$ of the Göksu riverine load. The total microplastics load of $101.2 \times 10^{9}$ items per year from the three Mersin WWTPs is only $9.7 \%$ of particles carried by the eight rivers sampled in our study. Seyhan and Berdan are the only two other rivers flowing to the Mersin Bay which were not sampled in our study. These two rivers also have substantial flow rates (Seyhan 106 $\mathrm{m}^{3} / \mathrm{s}$, Özpolat \& Demir, 2019 and Berdan $22.23 \mathrm{~m}^{3} / \mathrm{s}$, Ozbay et al., 2013). Inclusion of such high flow rates even assuming an average of 293 items $/ \mathrm{m}^{3}$ microplastic concentration would bring the total riverine load to Mersin Bay to over $2216 \times 10^{9}$ items per year.

The Mersin bay is among the most highly polluted regions in the Mediterranean affected by microplastics. Güven et al. (2017) and Gökdağ (2017) have reported concentrations as high as 172723 microplastic

Table 2. Comparison of riverine microplastics levels between this study and other sampled rivers

\begin{tabular}{|c|c|c|c|c|}
\hline Rivers & $\begin{array}{c}\text { Mesh size } \\
(\mu \mathrm{m})\end{array}$ & $\begin{array}{c}\text { Average (items } / \mathrm{m}^{3} \\
\pm \text { standard deviation) }\end{array}$ & $\begin{array}{c}\text { Range } \\
\text { (items } / \mathrm{m}^{3} \text { ) }\end{array}$ & Reference \\
\hline Mersin Rivers, Turkey & 26 & $293( \pm 59)$ & $95-613$ & Present study \\
\hline Brest Bay, France & 335 & $0.2( \pm 0.4)$ & & Frere et al., 2017 \\
\hline Danube River, Austria & 500 & 0.32 & & Lechner et al., 2014 \\
\hline Ottawa River, Canada & 100 & 1.4 & & Vermaire et al., 2017 \\
\hline Gave de Pau River, France & 330 & 3.3 & & Bruge et al., 2020 \\
\hline River Rhone, Switzerland & 300 & 7 & & Faure et al., 2015 \\
\hline Lam Tsuen River, Hong Kong & 270 & $7.4( \pm 3.7)$ & $1.3-14.0$ & Cheung et al., 2019 \\
\hline Ganges River, India & 330 & $38( \pm 4)$ & & Napper et al., 2021 \\
\hline Seine River, France & 80 & 108 & & Dris et al., 2018a \\
\hline Qiantang River, China & 45 & $1183( \pm 269)$ & $54-3379$ & Zhao et al., 2020 \\
\hline Ciwalengke River, Indonesia & 1.2 & $5850( \pm 3280)$ & & Alam et al., 2019 \\
\hline Chicago River, Illinois & 333 & & $1.9-17.9$ & McCormick et al., 2014 \\
\hline Ofanto River, Italy & 300 & & $0.9-13$ & Campanale et al., 2020b \\
\hline Rhône and Têt Rivers, France & 333 & & $12-42$ & Constant et al., 2020 \\
\hline Han River, South Korea & 100 & & $0-42.9$ & Park et al., 2019 \\
\hline Zhangjiang River, China & 330 & & $50-725$ & Pan et al., 2020 \\
\hline Antua River, Portugal & 55 & & $58-1265$ & Rodrigues et al., 2018 \\
\hline Wei River, China & 75 & & $3670-10700$ & Ding et al., 2019 \\
\hline Dutch Rivers, Holland & 300 & & $67-11532$ & Mintenig et al., 2020 \\
\hline Pearl River*, China & 50 & & $8902-19860$ & Yan et al., 2019 \\
\hline
\end{tabular}

*There is a wastewater treatment plant discharge

Table 3. Riverine microplastics load to Mersin Bay, the northeastern Mediterranean

\begin{tabular}{lccc}
\hline Location & Flow rate $\left(\mathrm{m}^{3} / \mathrm{s}\right)$ & Concentration $\left(\right.$ Items $\left./ \mathrm{m}^{3}\right)$ & Effluent rate (items/year) \\
\hline Alata & 1.96 & 252 & $15.58 \times 10^{9}$ \\
Arpaçbahşiş & 2.19 & 613 & $42.32 \times 10^{9}$ \\
Deliçay & 1.49 & 220 & $10.36 \times 10^{9}$ \\
Göksu & 98.61 & 344 & $1068.63 \times 10^{9}$ \\
Kandak & 2.32 & 271 & $19.86 \times 10^{9}$ \\
Lamas & 2.98 & 95 & $8.92 \times 10^{9}$ \\
Mezitli & 1.87 & 325 & $19.18 \times 10^{9}$ \\
Müftü & 2.2 & 223 & $15.47 \times 10^{9}$ \\
Total & 113.62 & --- & $1200.31 \times 10^{9}$ \\
\hline
\end{tabular}


particles $/ \mathrm{km}^{2}$ at the sea surface, 3.4 microplastic particles $/ \mathrm{m}^{3}$ in the water column, and 274 microplastic particles/L in the sediment. Considering the area and depth of Mersin Bay (see Figure 1), Akarsu et al. (2020) calculated a total volume of $175 \mathrm{~km}^{3}$ with microplastic content estimated at 595 billion particles using the aforementioned value of 3.4 items $/ \mathrm{m}^{3}$ for the water column. This figure corresponds to approx. a 6-month period of microplastics transport from the eight rivers sampled, or only a 3-month loading period when we include the Berdan and Seyhan rivers. Our results clearly show that rivers are an extremely important source of microplastics contamination in the marine environment.

\section{Conclusions}

This is the first study quantifying microplastics concentration and load transported from eight rivers to the Mersin bay in the northeastern Mediterranean. The predominant form and colour of MPs transported from the rivers investigated in this study were observed as fibres and blue, respectively. The bulk of microplastics (91\%) found in our study for riverine waters are less than $2.5 \mathrm{~mm}$ in length, very similar to the findings of Akarsu et al. (2020) for Mersin WTTP effluents and of Güven et al. (2017) for the marine environment in Mersin Bay. The most dominant polymer type determined from surface water samples is polyethylene (PE), which is the most widely used plastic type in the world. It has been ascertained that PE composed greenhouse plastic coverings used in agricultural cultivation contributes to the microplastics concentration in rivers.

Microplastic levels differed significantly among the rivers studied. The highest concentration of microplastics was found in the Arpaçbahşiş River (613 items $/ \mathrm{m}^{3}$ ), the lowest in the Lamas River $\left(95\right.$ items $/ \mathrm{m}^{3}$ ). However, due to a very high inflow rate, the Göksu river was estimated by far as the greatest contributor to the microplastics load for the recipient area of Mersin Bay in the northeastern Mediterranean. The total microplastics load from the eight rivers over a 6-month period was calculated as being equivalent to the total microplastics stock of the water column in Mersin Bay. Riverine loading for this study was calculated to be at least one order of magnitude higher than that reported for the three waste water treatment plants (WWTPs) from the same region earlier. Our study confirms that rivers are a major pathway for the transport of terrestrial microplastics to the marine environment. Considering that the population is mostly situated around rivers, estuaries and coastal areas, it is inevitable that the concentration of microplastics in aquatic ecosystems will continue to increase considering current plastic consumption. For this reason, it is necessary to conduct further research on the pathways and transport of microplastics via riverine systems for both better assessment and in developing solutions to the terrestrial litter problem.

\section{Ethical Statement}

Not applicable

\section{Funding Information}

There is no funding

\section{Author Contribution}

First author: Data Curation, Formal Analysis, Investigation; Second author: Methodology, Visualization and Writing -original draft; Third Author: Data Curation, Formal Analysis, Investigation; Fourth Author: Supervision, Data analysis, Writing - review and editing.

\section{Conflict of Interest}

We have no conflicts of interest to disclose.

\section{Acknowledgements}

The authors thank, Republic of Turkey Ministry of Agriculture and Forest Ankara Food Control Laboratory Directorate for providing facilities and support in doing FTIR analyzes work. We are grateful to Dr Ü. Aytan for her constructive comments.

\section{References}

Akarsu, C., Kumbur, H., Gökdağ, K., Kıdeyş, A.E., \& SanchezVidal, A. (2020). Microplastics composition and load from three wastewater treatment plants discharging into Mersin Bay, north eastern Mediterranean Sea. Marine Pollution Bulletin, 150, 110776. https://doi.org/10.1016/j.marpolbul.2019.110776

Alam, F.C., Sembiring, E., Muntalif, B.S., \& Suendo, V. (2019). Microplastic distribution in surface water and sediment river around slum and industrial area (case study: Ciwalengke River, Majalaya district, Indonesia). Chemosphere, 224, 637-645. https://doi.org/10.1016/j.chemosphere.2019.02.188

Alimi, O.S., Hernandez, L.M., \& Tufenkji, N. (2018). Microplastics and nanoplastics in aquatic environments: aggregation, deposition, and enhanced contaminant transport. Environmental Science \& Technology, 52, 1704-1724. https://doi.org/10.1021/acs.est.7b05559

Avio, C.G., Gorbi, S., \& Regoli, F. (2017). Plastics and microplastics in the oceans: From emerging pollutants to emerged threat. Marine Environmental Research, 128, 2 11. https://doi.org/10.1016/j.marenvres.2016.05.012

Aytan, U., Valente, A., Senturk, Y., Usta, R., Sahin, F.B.E., Mazlum, R.E. \& Agirbas E. (2016). First evaluation of neustonic microplastics in Black Sea waters. Marine Environmental Research, 119, 22-30.

https://doi.org/10.1016/j.marenvres.2016.05.009

Bellas, J., Martinez-Armental, J., Martinez-Camara, A., Besada, V. \& Martinez-Gomez, C. (2016). Ingestion of microplastics by demersal fish from the Spanish Atlantic and Mediterranean coasts. Marine Pollution Bulletin, 109, 55-60. 
https://doi.org/10.1016/j.marpolbul.2016.06.026

Belzagui, F., Crespi, M., Alvarez, A., Gutierrez-Bouzan, C. \& Vilaseca, M. (2019). Microplastics emissions: microfibers' detachment from textile garments. Environmental Pollution, 248, 1028-1035.

https://doi.org/10.1016/j.envpol.2019.02.059

Bruge, A., Dhamelincourt, M., Lanceleur, L., Monperrus, M., Gasperi, J. \& Tassin, B. (2020). A first estimation of uncertainties related to microplastic sampling in rivers. Science of the Total Environment, 718, 137319. https://doi.org/10.1016/j.scitotenv.2020.137319

Campanale, C., Savino, I., Pojar, I., Massarelli, C., \& Uricchio, V.F. (2020). A practical overview of methodologies for sampling and analysis of microplastics in riverine environments. Sustainability, 12, 6755. https://doi.org/10.3390/su12176755

Cheung, P.K. Fok, L., Hung, P.L., \& Cheung. L.T.O. (2018). Spatio-temporal comparison of neustonic microplastic density in Hong Kong waters under the influence of the Pearl River Estuary. Science of the Total Environment, 628-629, 731-739. https://doi.org/10.1016/j.scitotenv.2018.01.338

Cheung, P.K., Hung, P.L., \& Fok, L. (2019). River Microplastic Contamination and Dynamics upon a Rainfall Event in Hong Kong, China. Environmental Process, 6, 253-264. https://doi.org/10.1080/15321799408009632

Constant, M., Ludwig, W., Kerhervé, P., Sola, J., Charrière, B., Sanchez-Vidal, A., Canals, M., \& Heussner, S. (2020). Microplastic fluxes in a large and a small Mediterranean river catchments: The Têt and the Rhône, Northwestern Mediterranean Sea. Science of the Total Environment, 716, 136984.

https://doi.org/10.1016/j.scitotenv.2020.136984

Corradini, F., Casado, F., Leiva, V., Huerta-Lwanga, E., \& Geissen, V. (2021). Microplastics occurrence and frequency in soils under different land uses on a regional scale. Science of the Total Environment, 752, 141917. https://doi.org/10.1016/j.scitotenv.2020.141917

Cozar, A., Echevarria, F., Gonzalez-Gordillo, J., Irigoien, I.X., Ubedaa, B., Hernandez-Leon, S., Palma, A.T., Navarro, S., Garcia-de-Lomas, J., Ruiz, A., Fernandez-de-Puelles, M.L. \& Duarte, C.M. (2014). Plastic debris in the open ocean. Proceedings of the National Academy of Science, 111, 10239-10244. https://doi.org/10.1073/pnas.1314705111

Çullu, A.F., Sönmez, V.Z., \& Sivri, N. (2021). Microplastic contamination in surface waters of the Küçükçekmece Lagoon, Marmara Sea (Turkey): Sources and areal distribution. Environmental Pollution, 268, 115801. https://doi.org/10.1016/j.envpol.2020.115801

Dahms, H.T.J., van Rensburg, G.J., \& Greenfield, R. (2020). The microplastic profile of an urban African stream. Science of the Total Environment, 731, 138893. https://doi.org/10.1016/j.scitotenv.2020.138893

Dikareva, N., \& Simon, K.S. (2019). Microplastic pollution in streams spanning an urbanisation gradient. Environmental Pollution, 250, 292-299. https://doi.org/10.1016/j.envpol.2019.03.105

Ding, L., Mao R.F., Guo, X., Yang, X., Zhang, Q., \& Yang, C. (2019). Microplastics in surface waters and sediments of the Wei River, in the northwest of China. Science of the Total Environment, 667, 427-434.

https://doi.org/10.1016/j.scitotenv.2019.02.332
Dris, R., Gasperi, J., Rocher, V., \& Tassin, B. (2018). Synthetic and non-synthetic anthropogenic fibers in a river under the impact of Paris megacity: sampling methodological

aspects and flux estimations. Science of the Total Environment, 618, 157-164.

https://doi.org/10.1016/j.scitotenv.2017.11.009

DSI, General Directorate of State Hydraulic Works, www.dsi.gov.tr/Sayfa/Detay/744

Eerkes-Medrano, D., Thompson, R.C., \& Aldridge, D.C. (2015). Microplastics in freshwater systems: a review of the emerging threats, identification of knowledge gaps and prioritisation of research needs. Water Research, 75, 6382. https://doi.org/10.1016/j.watres.2015.02.012

Estahbanati, S., \& Fahrenfeld, N.L. (2016). Influence of wastewater treatment plant discharges on microplastic concentrations in surface water. Chemosphere, 162, 277-284.

https://doi.org/10.1016/j.chemosphere.2016.07.083

European Commission, (2013). Guidance on monitoring of marine litter in European seas. JRC Scientific reports. Joint Research Center - Institute for environment and sustainability. MSFD technical subgroup on marine litter. Luxembourg, p.124. http://dx.doi.org/10.2788/99475

Faure, F., Demars, C., Wieser, O., Kunz, M., \& De Alencastro, L.F. (2015). Plastic pollution in Swiss surface waters: nature and concentrations, interaction with pollutants. Environmental Chemistry, 12, 582-591. https://doi.org/10.1071/EN14218

Fazey, F.M.C., \& Ryan, P.G. (2016). Biofouling on buoyant marine plastics: an experimental study into the effect of size on surface longevity. Environmental Pollution, 210, 354-360. https://doi.org/10.1016/j.envpol.2016.01.026

Fortin, S., Song, B., \& Burbage, C. (2019). Quantifying and identifying microplastics in the effluent of advanced wastewater treatment systems using Raman microspectroscopy. Marine Pollution Bulletin, 149, 110579. https://doi.org/10.1016/j.marpolbul.2019.110579

Frere, L., Paul-Pont, I., Rinnert, E., Petton, S., Jaffre, J., Bihannic, I., Soudant, P., Lambe, C., \& Huvet, A. (2017). Influence of environmental and anthropogenic factors on the composition, concentration and spatial distribution of microplastics: A case study of the Bay of Brest (Brittany, France). Environmental Pollution, 225, 211-222. https://doi.org/10.1016/j.envpol.2017.03.023

Gonzalez-Fernandez, D., Pogojeva, M., Hanke, G., Machitadze, N., Kotelnikova, Y., Tretiak I., Gelashvili N., Kakhaber, B., Kulagin, D., Fedorov, A., Aleksey, Şenyiğit, M.Ç., \& Aytan, U. (2020). Anthropogenic Litter input through Rivers in the Black Sea. In Marine Litter in The Black Sea. Aytan, Ü., Pogojeva, M., Simeonova, A. (Eds.). Turkish Marine Research Foundation (TUDAV) Publication No: 56, Istanbul, TURKEY, 183-191.

González-Fernández D., A. Cózar, G. Hanke, J. Viejo, C. Morales-Caselles, R. Bakiu, D. Barceló, F. Bessa, A. Bruge, M. Cabrera, J. Castro-Jiménez, M. Constant, R. Crosti, Y. Galletti, Ahmet E Kideys, N. Machitadze, J. P. de Brito, M. Pogojeva, N. Ratola, J. Rigueira, E. Rojo-Nieto, O. Savenko, R. I. Schöneich-Argent, G. Siedlewicz, G. Suaria, $M$. Tourgeli (2021). Floating macro-litter leaked from Europe to the ocean. Nature Sustainability, 4: 474-483. https://doi.org/10.1038/s41893-021-00722-6.

Gündogdu, S., Çevik, C., Ayat, B., Aydoğan, B., \& Karaca, S. (2018). How microplastics quantities increase with flood events? An example from Mersin Bay NE Levantine coast 
of Turkey. Environmental Pollution, 239, 342-350. https://doi.org/10.1016/j.envpol.2018.04.042

Guven, O. (2021). Spatio-temporal distribution and characterization of microplastic pollution in the three main freshwater systems (Aksu and Köprü Streams, Manavgat River) and fishing grounds located in their vicinities in the Antalya Bay. Turkish Journal of Fisheries and Aquatic Sciences, 22(SI), TRJFAS20507. http://doi.org/10.4194/TRJFAS20507

Güven, O., Gökdağ, K., Jovanovic, B., \& Kıdeys, A.E. (2017). Microplastic litter composition of the Turkish territorial waters of theMediterranean Sea, and its occurrence in the gastrointestinal tract of fish. Environmental Pollution, 223, 286-294.

https://doi.org/10.1016/j.envpol.2017.01.025

He, B., Goonetilleke, A., Ayoko, G.A., \& Rintoul, L. (2020). Abundance, distribution patterns, and identification of microplastics in Brisbane River sediments, Australia. Science of the Total Environment, 700,134467. https://doi.org/10.1016/j.scitotenv.2019.134467

He, D., Luo, Y., Lu, S., Liu, M., Song, Y., \& Le, L. (2018). Microplastics in soils: Analytical methods, pollution characteristics and ecological risks. Trends in Analytical Chemistry, 109, 163-172.

https://doi.org/10.1016/j.trac.2018.10.006

Horton, A.A., \& Dixon, S.J. (2018). Microplastics: An introduction to environmental transport processes. WIREs Water, 5(2), e1268.

https://doi.org/10.1002/wat2.1268

Pagev, 2020

https://pagev.org/upload/files/Türkiye\%20Plastik\%20S ektör\%20izleme\%20Raporu\%202020\%20revize\%20\%28 3\%29.pdf

Hu, D., Zhang, Y., \&Shen, M. (2020). Investigation on microplastic pollution of Dongting Lake and its affiliated rivers. Marine Pollution Bulletin, 160, 111555. https://doi.org/10.1016/j.marpolbul.2020.111555

Hurley, R., \& Nizzetto, L. (2018). Fate and occurrence of micro(nano)plastics in soils:knowledge gaps and possible risks. Current Opinion Environmental Science \& Health, 1, 6-11. https://doi.org/10.1016/j.coesh.2017.10.006

Jambeck, J.R., Geyer, R., Wilco C., Siegler, T.R., Perryman, M., Andrady, A., Narayan, R., \& Law, K.L. (2015). Plastic waste inputs from land into the ocean. Science, 13; 347(6223), 768-71. https:// 10.1126/science.1260352

Kowalski, N., Reichardt, A.M., \& Waniek, J.J. (2016). Sinking rates of microplastics and potential implications of their alteration by physical, biological, and chemical factors. Marine Pollution Bulletin, 109, 310-319. https://doi.org/10.1016/j.marpolbul.2016.05.064

Lam, T.W.L., Foka, L., Linb, L., Xieb, Q., Li, H.X., Xu, X.R., \& Yeung, L.C. (2020). Spatial variation of floatable plastic debris and microplastics in the Pearl River Estuary, South China. Marine Pollution Bulletin, 158, 111383. https://doi.org/10.1016/j.marpolbul.2020.111383

Lebreton, L.C.M., Van der Zwet, J., Damsteeg, J.W., Slat, B., Andrady, A., \& Reisser, J. (2017). River plastic emissions to the world's oceans. Nature Communications, 8, 15611. https://doi.org/10.1038/ncomms15611

Lechner, A., Keckeis, H., Lumesberger-Loisl, F., Zens, B., Krusch, R., Tritthart, M., Glas, M., \& Schludermann, E. (2014). The Danube so colourful: a potpourri of plastic litter outnumbers fish larvae in Europe's second largest river. Environmenral Pollution, 188, 177-181.

https://doi.org/10.1016/j.envpol.2014.02.006
Lin, L., Zuo, L.Z., Peng, J.P., Cai, L.Q., Fok, L., Yan, Y., Li, H.X., \& Xu, X.R. (2018). Occurrence and distribution of microplastics in an urban river: A case study in the Pearl River along Guangzhou City, China. Science of the Total Environment, 644, 375-381.

https://doi.org/10.1016/j.scitotenv.2018.06.327

Liu, M., Lu, S., Song, Y., Lei, L., Hu, J., Lv, W., Zhou, W., Cao, C., Shi, H., Yang, X., \& He, D. (2018). Microplastic and mesoplastic pollution in farmland soils in suburbs of Shanghai, China. Environmental Pollution, 242, 855-862. https://doi.org/10.1016/j.envpol.2018.07.051

Liu, K., Wang, X., Fang, T., Xu, P., Zhu, L., \& Li, D. (2019). Source and potential risk assessment of suspended atmospheric microplastics in Shanghai. Science of the Total Environment, 675, 462-471.

https://doi.org/10.1016/j.scitotenv.2019.04.110

Mason, S.A., Garneau, D., Sutton, R., Chu, Y., Ehmann, K., Barnes, J., Fink, P., Papazissimos, D., \& Rogers, D.L. (2016). Microplastic pollution is widely detected in US municipal wastewater treatment plant effluent. Environmental Pollution, 218, 1045-1054. https://doi.org/10.1016/j.envpol.2016.08.056

McCormick, A., Hoellein, T.J., Mason, S.A., Schluep, J., \& Kelly, J.J. (2014). Microplastic is an abundant and distinct microbial habitat in an urban river. Environmental Science \& Technology, 48, 11863-11871. https://doi.org/10.1021/es503610r

Meijer, L.J.J., Van Emmerik, T., van Der Ent, R., Schmidt, C., \& Lebreton, L. (2021). Over 1,000 rivers accountable for $80 \%$ of global riverine plastic emissions into the ocean. Science Advances, 7(18), 1-13. https://doi.org/10.1126/sciadv.aaz5803

Mintenig, S.M., Kooi, M., Erich, M.W., Primpke, S., RedondoHasselerharm, P.E., Dekker, S.C., Koelmans, A.A., \& van Wezel A.P. (2020). A systems approach to understand microplastic occurrence and variability in Dutch riverine surface waters. Water Research, 176, 115723. https://doi.org/10.1016/j.watres.2020.115723

Napper, I.E., Baroth, A., Barrett, A.C., Bhola, S., Chowdhury, G.W., Davies, B.F.R., Duncan, E.M., Kumar, S., Nelms, S.E., Niloy, N.H., Nishat, B., Maddalene, T., Thompson, R.C., \& Koldewey, H. (2021). The abundance and characteristics of microplastics in surface water in the transboundary Ganges River. Environmental Pollution, $274,116348$.

https://doi.org/10.1016/j.envpol.2020.116348

Napper, I.E., \& Thompson, R.C. (2016). Release of synthetic microplastic plastic fibres from domestic washing machines: effects of fabric type and washing conditions. Marine Pollution Bulletin, 112, 39-45. https://doi.org/10.1016/j.marpolbul.2016.09.025

Özbay, Ö., Göksu, M., Alp, M.T., \& Sungur, M.A. (2013). Berdan Çayı (Tarsus-Mersin) sedimentinde ağır metal düzeylerinin araştırılması. Ekoloji Dergisi, 22(86), 68-74. https://doi.org/10.5053/ekoloji.2013.868

Özpolat, E., \& Demir, T. (2019). The spatiotemporal shoreline dynamics of a delta under natural and anthropogenic conditions from 1950 to 2018: A dramatic case from the Eastern Mediterranean. Ocean and Coastal Management, 180, 104910. https://doi.org/10.1016/j.ocecoaman.2019.104910

Pan, Z., Liu, Q., Jiang, R., Li, W., Sun, X., Lin, H., Jiang, S., \& Huang, H. (2021). Microplastic pollution and ecological risk assessment in an estuarine environment: The 
Dongshan Bay of China. Chemosphere 262, 127876. https://doi.org/10.1016/j.chemosphere.2020.127876

Pan, Z., Liu, Q., Sun, Y., Sun, X., \& Lin, H. (2019). Environmental implications of microplastic pollution in the Northwestern Pacific Ocean. Marine Pollution Bulletin, 146, 215-224. https://doi.org/10.1016/j.marpolbul.2019.06.031

Pan, Z., Sun, Y., Liu, Q., Lin, C., Sun, X., He, Q., Zhou, K., \& Lin, H. (2020). Riverine microplastic pollution matters: A case study in the Zhangjiang River of Southeastern China. Marine Pollution Bulletin, 159, 111516. https://doi.org/10.1016/j.marpolbul.2020.111516

Park, T.J., Lee, S.H., Lee, M.S., Lee, J.K. Lee, S.H., \& Zoh, K.D. (2020). Occurrence of microplastics in the Han River and riverine fish in South Korea. Science of the Total Environment, 708, 134535. https://doi.org/10.1016/j.scitotenv.2019.134535

Pellini, G., Gomiero, A., Fortibuoni, T., Ferrà, C., Grati, F., Tassetti, A.N., Polidori, P., Fabi, G., \& Scarcella, G. (2018). Characterization of microplastic litter in the gastrointestinal tract of Solea solea from the Adriatic Sea. Environmental Pollution, 234, 943-952. https://doi.org/10.1016/j.envpol.2017.12.038

PlasticsEurope, 2019. Plastics - the facts 2019: an analysis of European plastic production, demand and waste data. Plastics Europe, Belgium

https://www.plasticseurope.org/application/files/9715 /7129/9584/FINAL_web_version_Plastics_the_facts201 9_14102019.pdf

Rodrigues, M.O., Abrantes, N., Gonçalves, F.J.M., Nogueira, H., Marques, J.C., \& Gonçalves, A.M.M. (2018). Spatial and temporal distribution of microplastics in water and sediments of a freshwater system (Antuã River, Portugal). Science of the Total Environment, 633, 15491559. https://doi.org/10.1016/j.scitotenv.2018.03.233

Ryan, P.G., Moore, C.J., van Franeker, J.A., \& Moloney, C.L. (2009). Monitoring the abundance of plastic debris in the marine environment. Philosophical Transactions of the Royal Society. B Biological Sciences, 364, 1999-2012. https://doi.org/10.1098/rstb.2008.0207

Sang, W., Chen, Z., Mei, L., Hao, S., Zhan, C., Zhang, W., \& Liu, J. (2021). The abundance and characteristics of microplastics in rainwater pipelines in Wuhan, China. Science of the Total Environment, 755,142606. https://doi.org/10.1016/j.scitotenv.2020.142606

Schwarz, A.E., Ligthart, T.N., Boukris, E., \& Van Harmelen, T. (2019). Sources, transport, and accumulation of different types of plastic litter in aquatic environments: A review study. Marine Pollution Bulletin, 143, 92-100. https://doi.org/10.1016/j.marpolbul.2019.04.029

Sebille, E.V., Wilcox, C., Lebreton, L., Maximenko, N., Hardesty, B.D., van Franeker, J.A., Eriksen, M., Siegel, D., Galgani, F., \& Law, K.L. (2015). A global inventory of small floating plastic debris. Environmental Research Letters, 10, 124006. http://dx.doi.org/10.1088/1748-9326/10/12/124006

Skalska, K., Ockelford, A., Ebdon, J.E., \& Cundy, A.B. (2020). Riverine microplastics: Behaviour, spatio-temporal variability, and recommendations for standardised sampling and monitoring. Journal of Water Process Engineering, 38, 101600. https://doi.org/10.1016/j.jwpe.2020.101600

Su, L., Deng, H., Li, B., Chen, Q., Pettigrove, V., Wu, C., \& Shi, H. (2019). The occurrence of microplastic in specific organs in commercially caught fishes from coast and estuary area of east China. Journal of Hazardous Materials, 365, 716-724.

https://doi.org/10.1016/j.jhazmat.2018.11.024

Sun, J., Dai, X., Wang, Q., van Loosdrecht, M.C.M., \& Ni, B. (2019). Microplastics in wastewater treatment plants: detection, occurrence and removal. Water Research, 152, 21-37. https://doi.org/10.1016/j.watres.2018.12.050

Sun, X., Liang, J., Zhu, M., Zhao, Y., \& Zhang, B. (2018). Microplastics in seawater and zooplankton from the Yellow Sea. Environmental Pollution, 242, 585-595. https://doi.org/10.1016/j.envpol.2018.07.014

Thompson, R. C., Moore, C., Vom Saal, F. S. \& Swan, S. H. (2009). Plastics, the environment and human health: current consensus and future trends. Philosophical Transactions of the Royal Society. B Biological Sciences, 364(1526):2153-2166.

https://dx.doi.org/10.1098\%2Frstb.2009.0053

Tubau, X., Canals, M., Lastras, G., Rayo, X., Rivera, J., \& Amblas, D. (2015). Marine litter on the floor of deep submarine canyons of the northwestern Mediterranean Sea: The role of hydrodynamic processes. Progress in Oceanography, 134, 379-403.

https://doi.org/10.1016/j.pocean.2015.03.013

Vermaire, J.C., Pomeroy, C., Herczegh, S.M., Haggart, O., \& Murphy, M. (2017). Microplastic abundance and distribution in the open water and sediment of the Ottawa River, Canada, and its tributaries. Facets, 2, 301314. https://doi.org/10.1139/facets-2016-0070

Wang, S., Zhang, C., Pan, Z., Sun, D., Zhou, A., Xie, S., Wang, J., \& Zou, J. (2020). Microplastics in wild freshwater fish of different feeding habits from Beijiang and Pearl River Delta regions, south China. Chemosphere. 258, 127345. https://doi.org/10.1016/j.chemosphere.2020.127345

Wang, W., Ndungu, A.W., Li, Z., \& Wang, J. (2017). Microplastics pollution in inland freshwaters of China: a case study in urban surface waters of Wuhan, China. Science of the Total Environment, 575, 1369-1374. https://doi.org/10.1016/j.scitotenv.2016.09.213

WWF (2018). Out of the plastic trap: Saving the Mediterranean from plastic pollution.

http://ocean.panda.org.s3.amazonaws.com/media/OU T\%20OF\%20THE\%20PLASTIC\%20TRAP/WWF_Plastics_ MED_WEB.pdf.

Wright, S.L., Thompson, R.C., \& Galloway, T.S. (2013). The physical impacts of microplastics on marine organisms: A review. Environmental Pollution, 178, 483-492. https://doi.org/10.1016/j.envpol.2013.02.031

Xia, W., Rao Q., Deng, X., Chen, J., \& Xie, P. (2020). Rainfall is a significant environmental factor of microplastic pollution in inland waters. Science of the Total Environment, 732, 139065.

https://doi.org/10.1016/j.scitotenv.2020.139065

Xiong, X., Wu, C., Elser, J.J., Mei, Z., \& Hao, Y. (2019). Occurrence and fate of microplastic debris in middle and lower reaches of the Yangtze River - from inland to the sea. Science of the Total Environment, 659, 66-73. https://doi.org/10.1016/j.scitotenv.2018.12.313

Yabanlı, M. Yozukmaz, A., Şener, İ., \& Ölmez, Ö.T. (2019). Microplastic pollution at the intersection of the Aegean and Mediterranean Seas: A study of the Datça Peninsula (Turkey). Marine Pollution Bulletin, 145, 47-55. https://doi.org/10.1016/j.marpolbul.2019.05.003

Yan, M., Nie, H., Xu, K., He, Y., Hu, Y., Huang, Y., \& Wang, J. (2019). Microplastic abundance, distribution and 
composition in the Pearl River along Guangzhou city and Pearl River estuary, China. Chemosphere. 217, 879-886. https://doi.org/10.1016/j.chemosphere.2018.11.093

Yu, Q., Hu, X., Yang, B., Zhang, G., Wang, J., \& Ling W. (2020). Distribution, abundance and risks of microplastics in the environment. Chemosphere. 249, 126059. https://doi.org/10.1016/j.chemosphere.2020.126059

Zhang, K., Gong, W., Lv, J., Xiong, X., \& Wu, C. (2015). Accumulation of floating microplastics behind the three Gorges dam. Environmental Pollution, 204, 117-123. https://doi.org/10.1016/j.envpol.2015.04.023

Zhang, W., Zhang, S., Wang, J., Wang, Y., Mu, J., Wang, P., Lin, X., \& Ma, D. (2017). Microplastic pollution in the surface waters of the Bohai Sea China. Environmental Pollution, 231, 541-548.

https://doi.org/10.1016/j.envpol.2017.08.058
Zhao, W., Huang, W., Yin, M., Huang, P., Ding, Y., Ni, X., Xia, H., Liu, H., Wang, G., Zheng, H., \& Ca, M. (2020). Tributary inflows enhance the microplastic load in the estuary: $A$ case from the Qiantang River. Marine Pollution Bulletin, 156, 111152.

https://doi.org/10.1016/j.marpolbul.2020.111152

Zheng, Y., Li, J., Cao, W., Liu, X., Jiang, F., Ding, J., Yin, X., \& Sun, C. (2019). Distribution characteristics of microplastics in the seawater and sediment: a case study in Jiaozhou Bay, China. Science of the Total Environment, 674, 27-35. https://doi.org/10.1016/j.scitotenv.2019.04.008 